\title{
PENGARUH HARGA DAN INOVASI PRODUK SERTA GAYA HIDUP TERHADAP KEPUTUSAN PEMBELIAN KAIN ENDEK DI PASAR SEMARAPURA
}

\author{
I.A.D. Atnawati ${ }^{1}$, N.M.A. Widiastini ${ }^{2}$ \\ 1,2 Jurusan Mananjemen, Universitas Pendidikan Ganesha, Singaraja \\ e-mail: dayudevi65@gmail.com,nimadearywidiastini.undiksha@gmail.com
}

\begin{abstract}
Abstrak
Penelitian ini memiliki maksud untuk melakukan uji atas pengaruh dari harga, inovasi produk, dan gaya hidup, harga, inovasi produk, dangaya hidup terhadap keputusan pembelian. Metode yang digunakan penelitian ini yaitu pendekatan kuantitatif. Konsumen kain endek di pasar Semarapura menjadi subjek penelitian sedangkan pengaruh harga, inovasi produk, dan gaya hidup terhadap keputusan pembelian menjadi objek pada penelitian. Hasil penelitian ini menunjukkan bahwa (1) Harga, inovasi produk dan gaya hidup berpengaruh positif dan signifikan terhadap keputusan pembelian kain endek di Pasar Semarapura, (2) Harga berpengaruh positif dan signifikan terhadap keputusan pembelian kain endek di Pasar Semarapura, (3) Inovasi produk berpengaruh negatif dan signifikan terhadap keputusan pembelian kain endek di Pasar Semapura., (4) Gaya hidup berpengaruh positif dan signifikan terhadap keputusan pembelian kain endek di Pasar Semarapura.
\end{abstract}

Kata kunci: gaya hidup, harga, inovasi produk, dan keputusan pembelian

This study aims to test the effect of price, product innovation, and lifestyle, price, product innovation and lifestyle on purchasing decisions. The method used in this research is a quantitative approach. Consumers of endek fabrics in the Semarapur market are the research subjects while the influence of price, product innovation, and lifestyle on purchasing decisions is the object of the study. The results of this study indicate that (1) Price, product innovation and lifestyle have a positive and significant effect on purchasing decisions for endek fabrics at Semarapura Market, (2) Prices have a positive and significant effect on purchasing decisions for endek fabrics at Semarapura markets, (3) Product innovation. has a negative and significant effect on purchasing decisions for endek fabrics at the Semarapura Market. (4) Lifestyle has a positive and significant effect on purchasing decisions for endek fabrics in the Semarapura market.

Keywords: lifestyle, price, product innovation, and purchase decisions.

\section{Pendahuluan}

Di masa modernisasi sekarang, perusahaan dihadapkan pada persaingan khususnya di bidang perekonomian yang bersaing. Tuntutan persaingan memaksa perusahaan untuk mengikuti keinginan konsumen dan perubahan pasar, agar perusahaan mampu bersaing dengan pihak pesaing serta mempertahankan produknnya di pasaran. Perubahan yang dimaksud yaitu bagaimana perusahaan mampu berinovasi dalam memenuhi kebutuhandari konsumen, berkompetisi dengan pesaing usaha lain serta mengikuti trend pasar. Perusahaan melakukan inovasi - inovasi dengan harapan agar dapat melahirkan produk baru atau mengembangkan produk yang ada. Tentunya dalam membeli sebuah produk atau mengkonsumsi sebuah produk, tidak sebatas hanya mengetahui nilai dan juga fungsinya, disisi lain konsumen juga meihat kelebihan produk dibanding produk sejenis yang lainnya. Hal ini lah yang menjadi dasar bagi produsen untuk terus melaksanakan inovasi pada produk. Jasfar (2012) dalam Nathaniel (2019) memaparkan bahwa inovasi merupakan hasil dari seberapa kreatif dilandasi juga dengan ilmu yang dimiliki serta kecanggihan dari teknoligi dalam perubahan barang / jasa menjadi bernilai lebih.Jika perkembangan inovasi berhasil, maka bisa dijadikan strategi yang kuat untuk bertahan dipasar, dibandingkan para pesaing yang selalu tampil dinamis (Kensinger, 1997 dalam Melia dkk, produk milik pesaing lebih berinovasi dari tahun ke 
tahun (Kensinger, 1997 dalam Melia dkk,2015).

Salah satu industri kerajinan yang saat ini semakin berkembang adalah kerajinan

tenun. Hal tersebut menuntut perusahaan agar dapat memahami dan memenuhi permintaan konsumen. Perusahaan harus mengetahui latar belakang dari pertimbangan para pembeli dalam mempertibangkan barang yang ingin konsumen beli khusunya produk kerajinan tenun (Waskianari dan Sulistyawati, 2013). Saputra, dkk (2015) dengan judul Pengaruh Inovasi Produk dan Promosi Terhadap Keputusan Pembelian pada Distro Klanrock House Concept Store di Jember disimpulkan inovasi produk dan promosi berpengaruh secara parsial dan simultan terhadap keptusan pembelian.Sedangkan, Abdillah (2017) menyatakan bahwa inovasi produk memiliki pengaruh terhadap keputusan pembelian melalui kepuasan konsumen, akan tetapi inovasi produk tidak memiliki pengaruh secara langsung terhadap keputusan pembelian ulanghijab.

Kini Fashion menjadi bagian penting yang tidak bisa terpisahkan dengan penampilan gaya keseharian. Modernisasi juga dapat dilihat dari gaya hidup yang mengikuti trend dan mengacu pada baju ataupun aksesoris yang dipakai, selain sebagai hiasan dan penutup tubuh juga bisa sebagai alat komunikasi untuk identitas diri. Setiadi (2003) mengatakan bahwa life style secara umum diartikan sebagai bagaimana waktu seseorang digunakan atau aktivitas, apa yang di prioritaskan atau ketertarikan serta apa yang mereka pikirkan tentang dirinya sendiri juga lingkungannya atau opini. Sedangkan Sumarwan (2011) mengatakan bahwa gaya hidup itu mendeskripsikan bagaimana seseorang berprilaku, bagaimana hidupnya, mamanfaatkan uangnya dan juga menghabiskan waktunya.

Gaya hidup masyarakat satu dengan yang lainnya tidak selalu sama, dari waktu ke waktu pun gaya hidup akan selalu berubah - ubah namun tidak cepat sehingga dalam beberapa waktu gaya hidup relatif tetap (Hendariningrum, 2008). Nathaniel, dkk (2019) melakukan penelitian yang mendukung penelitian ini terkait pengaruh gaya hidup dan inovasi produk terhadap keputusan pembelian produk dengan hasil keputusan pembelian baik secara parsiam atau simultan tidak dipengaruhi oleh gaya hidup dan inovasi produk. Sedangkan, Amelia (2016) mendapatkan keputusan pembelian hidup. Agustina (2019) pun sependapat bahwa keputusan pembelian secara parsial tidak dipengaruhi oleh gaya hidup, harga, promosi, citra merek, dan viral marketing.

Bali merupakan satu dari beberapa daerah di Indonesia yang sektor industrinya berkembang secara pesat, contohnya pada industri kain tenun endek di Kab. Klungkung. Hal ini didukung dengan PERGUB Bali No. 79 Tahun 2018 Tentang Hari Penggunaan Busana Adat Bali, yang menyebabkan peningkatan jumlah pesanan kain tenun. Ini dirasakan para pengrajin di Kabupaten Klungkung salah satunya pemilik Pertenunan Astiti yang mengungkapkan, sebelum Pergup tersebut ada, penjualan produk kain tenun produksinya cukup lesu. Apalagi produk para pengrajin di Klungkung merupakan produk yang dibuat dengan Alat Tenun Bukan Mesin (ATMB). Selain dengan peraturan gubernur, pemasaran kain endek juga didukung oleh pemerintah Kabupaten Klungkung dengan menggelar pelaksanaan SemarapuraFashion Day. Serta adanya fasilitas yang disediakan oleh pemerintah Kabupaten Klungkung sebagai tempat penjualan kain.

Bali merupakan satu dari beberapa daerah di Indonesia yang sektor industrinya berkembang secara pesat, contohnya pada industri kain tenun endek di Kab. Klungkung. Hal ini didukung dengan PERGUB Bali No. 79 Tahun 2018 Tentang Hari Penggunaan Busana Adat Bali, yang menyebabkan peningkatan jumlah pesanan kain tenun. Ini dirasakan para pengrajin di Kabupaten Klungkung salah satunya pemilik Pertenunan Astiti yang mengungkapkan, sebelum Pergup tersebut ada, penjualan produk kain tenun produksinya cukup lesu. Apalagi produk para pengrajin di Klungkung merupakan produk yang dibuat dengan Alat Tenun Bukan Mesin (ATMB). Selain dengan peraturan gubernur, pemasaran kain endek juga didukung oleh pemerintah Kabupaten Klungkung dengan menggelar pelaksanaan SemarapuraFashion Day. Serta adanya fasilitas yang disediakan oleh pemerintah Kabupaten Klungkung sebagai tempat penjualan kain.

Dalam menentukkan gaya hidup harga cukuplah berpengaruh dalam menentukkan posisi konsumen dalam memilih sebuah produk nantinya. Harga adalah pemberian untuk 
pelanggan agar mendapatkan keunggulan dari produk yangditawarkan oleh bauran pemasaran perusahaan (Cannon,dkk. 2008). Dalam hal ini harga juga berperan sebagai penentu dalam pembelian suatu produk, konsumen akan menentukan apakah harga tersebut telah mencapai kesepakatan. Saat produsen menentukan harga, maka harus berorientasi kepada pembeli agar konsumen mendapat nilai atau manfaat barang dengan menukar suatu harga. Jika pelanggan merasakan harga yang terlalu tinggi tidak sesuai dengan nilai produk, maka kemungkinan besar pelanggan akan mengundurkan niatnya untuk membeli produk. sebaliknya, jika pembeli merasakan bahwa nilai produk lebih besar Jika konsumen menganggap harga berada di bawah nilai produk, maka pembeli akan tertarik untuk membeli. Jailani (2013) menyimpulkan harga sebagai salah satu faktor yang memiliki pengaruh signifikan terhadap keputusan pembelian konsumen. Sedangkan, Saraswati, dkk (2014) dengan hasil penelitian keputusan pembelian tidak dipengaruhi oleh harga. Searah dengan Murwatiningsih dan Apriliani (2013) keputusan pembelian onlinemelalui kepercayaan konsumen sebagai variabelmediasi dipengaruhi secara signifikan oleh harga.

Adanya gap research dari hasil penelitian sebelumnya mengenai gaya hidup, harga dan inovasi produk menjadi motivasi peneliti untuk mengangkat judul penelitian ini. Dipilihnya industri endek dikarenakan industri endek merupakan sektor industri yang paling diminati dalam pasar lokal khususnya di Bali. Serta dipilinnya pasar Semarapura dikarenakan, pasar Semarapura merupakan pusat penjualan kain endek terbesar diKabupatenKlungkung. Serta dipilihnya Kabupaten Klungkungdikarenakan, Kabupaten Klungkungmerupakan ikon penjualan kain di Bali. Hal ini didukung oleh Badan Pusat Statistik Kabupaten Klungkung 2018, yang menyatakan Kabupaten Klungkungmemiliki penghasil tekstil sebanyak 729 usaha dari usaha rumah tangga hingga usaha skala besar.

Berdasarkan latar belakang diatas, maka didapat rumusan masalah ; (1) Bagaimana pengaruh harga, inovasi produk dan gaya hidup terhadap keputusan pembelian? (2) Bagaimana pengaruh harga terhadap keputusan pembelian? (3) Bagaimana pengaruh inovasi produk terhadap keputusan pembelian? (4) Bagaimana pengaruh gaya hidup terhadap keputusanpembelian?

Peneliti memiliki tujuan dalam penelitian untuk mengetahui :(1) Pengaruh harga, inovasi produk, dan gaya hidup terhadap keputusan pembelian, (2) Pengaruh harga terhadap keputusan pembelian, (3) Pengaruh inovasi produk terhadap keputusan pmbelian, (4) Pengaruh gaya hidup terhadap keputusan pembelian.

Penulis berharap penelitian ini memiliki manfaat : (1) Dari segi manfaat teoritis, diharapkan bisa memberi manfaat bagi akademisi mengenai manajemen pemasaran, (2) Manfaat praktis, diharapkan agar menjadi tambahan referensi mengenai harga, inovasi produk, dan gaya hidup terhadap keputusan pembelian serta dapat memberikan gambaran yang lebih nyata mengenai harga, inovasi produk dan gaya hidup terhadap pembelian kain endek.

Shaleh (2017), kepuasan pembelian dipengaruhi secara positif dan signifikan oleh inovasi produk, gaya hidup dan harga. Berdasarkan hasil penelitian yang telah dikemukakan maka diambil hipotesis, berikut :

$\mathrm{H} 1$ :Ada pengaruh harga, inovasi produk dan gaya hidup terhadap keputusan pembelian. Harga berhubungan dengan keputusan pembelian karena semakin tinggi harga, maka semakin rendahnya keputusan pembelian (Kotler dan Amstrong, 2005), maka para pengusaha harus teliti dalam menentukan harga produk agar dapat memenangkan pasar. Jailani (2013) dengan hasil penelitian keputusan pembelian dipengaruhi secara positif oleh harga. Karena harga ang dibandrol lebih ekonomis daripada harga produk pesaing sejenis padahal kualitasnya sama, sehingga konsumen merasa diuntungkan. Berdasarkan hasil penelitian yang telah dikemukakan maka diambil hipotesis, berikut. H2 : Ada pengaruh harga terhadap keputusan pembelian. Kotabe menyatakan tingginya inovasi dari produk yang dilakukan organisasi, maka akan meningkat juga kinerja dari perusahaan dilihat dari naiknya keputusan konsumen dalam membeli produk, Tamamudin (2012:289). Sejalan dengan Susanto (2013) dengan hasil inovasi produk berpengaruh positif da signifikan terhadap keputusanpembelian. 
Berdasarkan hasil penelitian yang telah dikemukakan maka diambil hipotesis, berikut. H3 : Ada pengaruh inovasi produk terhadap keputusan pembelian. Gaya hidup dapat mempengaruhi keinginan seseorang untuk berperilaku dan akhirnya menentukan pilihan -pilihan konsumsi seseorang (Kasalli, 2005). Shaleh (2017), menyimpulkan bahwa keputusan pembelian dipengaruhi secara positif dan signifikan oleh gaya hidup. Berdasarkan hasil penelitian yang telah dikemukakan maka diambil hipotesis, berikut : H4: Ada pengaruh gaya hidup terhadap keputusan pembelian.

\section{Metode}

Penelitian dengan pendekatan kuantitatif dalam menguji hipotesis yang telah disusun serta menemukan ada atau tidak hubungan antara dua atau lebih dari variabel yang akan diukur. Subjek dalam penelitian ini adalah konsumen yang membeli kain endek di pasar Semarapura. Objek dalam penelitian ini adalah pengaruh harga, inovasi produk, dan gaya hidup terhadap keputusan pembelian. Penelitian ini menggunakan empat variabel, yaitu Harga $\left(\mathrm{X}_{1}\right)$, Inovasi Produk $\left(\mathrm{X}_{2}\right)$, Gaya Hidup $\left(\mathrm{X}_{3}\right)$, dan Keputusan Pembelian $(\mathrm{Y})$.

Penelitian ini termasuk ke dalam penelitian sampel. Konsumen di pasar tradisional Semarapura, Kab. Klungkung. yang membelikain endek merupakan sampel penelitian. Teknik pengambilan sampel yang digunakan dengan teknik accidental sampling, dimana penentuan sampel diambil tanpa sengaja.Dalam penelitian ini jumlah sampel representative menurut Kiswati (2010) adalah tergantung pada jumlah indikator dikali 5 sampai10.

Jumlah sampel minimum dalam penelitian ini sebanyak $14 \times 5=70$. Sedangkan jumlah sampel maksimum yaitu sebanyak $14 \times 10=140$.Berdasarkan perhitungan di atas maka sampel yang digunakan dalam penelitian ini yaitu sebanyak 95 responden untuk mengantisipai apabila data tidak valid. Penelitian ini menggunakan data primer saat mengumpulkan data dengan kuesioner lalu diolah data yang didapat. Dari data skunder yaitu penggunaan skalalikert dengan Badan Pusat Statistik Kab. Kelungkung.

Metode dan teknik analisis data yang digunakan dalam penelitian ini adalah analisis regresi linier berganda dengan melakukan uji pengujian sebagai berikut: (1) Uji instrumen menggunakan uji reliabilitas dan uji validitas, (2) Uji asumsi klasik menggunakan uji multikolonieritas, uji normalitas dan uji heteroskedastisitas, (3) Uji regresi linier berganda dan (4) Uji hipotesis yang meliputi uji signifikan simultan (uji statistik F) dan uji signifikan paramete individual (uji t) menggunakan SPSS versi 20.0.

\section{Hasil Dan Pembahasan}

Berdasarkan hasil uji validitas bisa dilihat semua item masing- masing variabel dinyatakan valid karena skor total signifikan $p$-value $<$ alpha $0,05(p<0,05)$.

Uji Reliabilitas

Tabel 1

Hasil Uji Reliabilitas

\begin{tabular}{ccc}
\hline Variabel & Koefisien Reliabilitas & Keterangan \\
\hline Harga $(X 1)$ & 0,731 & Reliabel \\
& 0,772 & Reliabel \\
& 0,791 & Reliabel \\
Inovasi Produk $(X 2)$ & 0,878 & Reliabel \\
& 0,659 & Reliabel \\
Gaya Hidup $(X 3)$ & 0,659 & Reliabel \\
& 0,615 & Reliabel \\
& 0,737 & Reliabel \\
& 0,666 & Reliabel \\
& 0,716 & Reliabel \\
& 0,691 & Reliabel \\
& 0,640 & Reliabel \\
& 0,666 & Reliabel \\
\hline
\end{tabular}

Bisma: Jurnal Manajemen | 100 
Berdasarkan Tabel 1 dari empat butir pernyataan pada variabel $\mathrm{X}_{1}$, empat butir pernyataan pada variabel $X_{2}$ dinyatakan dan enam butir pernyataan pada variabel $X_{3}$ reliabel. $\mathrm{Hal}$ ini ditunjukkan dengan nilai syarat reliabel $>0.60$. Jadi dapat diungkap bahwa instrumen variabel bebas yaitu harga, inovasi produk serta gaya hidup secara keseluruhan reliabel.

Ghozali (2011) sasaran uji normalitas adalah untuk melihat model regresi variabel $Y$ dengan variabel $X$ memiliki hubungan atau tidak.Dikatakan model regresi yang baik jika datanya berdistribusi normal dengan berlandaskan pengambilan keputusan pemenuhan normalitas, yaitu 1) penyebaran data yang mengikuti grafik histogram menunjukkan data berdistribusi normal, 2) jika data menyebar jauh dari arah diagonal artinya data tidak berdistribusi normal atau tidak memenuhi syarat asumsi dari tahap ini. Berikut hasil ptobability plot.

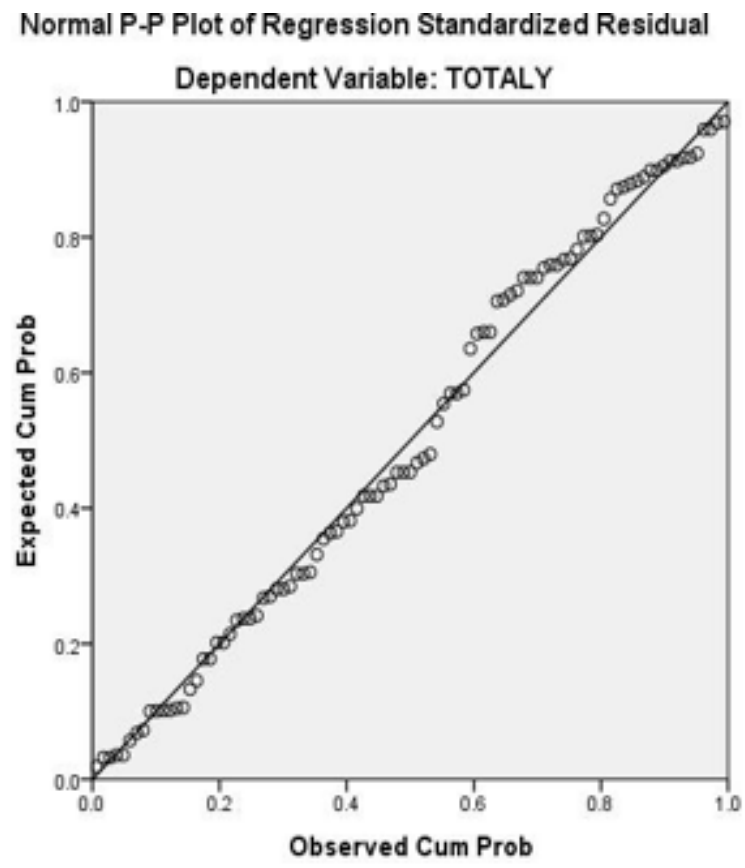

\section{Gambar 1.}

\section{Grafik Normal P.P Plots of Regression Standardized Residual}

Berdasarkan Gambar 1. Dapat dilihat bahwa penyebaran data mengikuti arah garis diagonal, artinya model regresi yang di pakai berdistribusi normal.

Ghozali (2011) mengatakan uji multikolinearitas bermaksud untuk menguji suatu model regresi adakah korelasi antar variabel bebas. Pengujianmultikolinearitas dilihat dari besar VIF dan tolerance.Tolerancedipakai untuk mengukur variabel Xpenelitian yang tidak dijelaskan oleh variabel $X$ lainnya. Jika nilai tolerance yang rendah $=$ nilai VIF tinggi (karena VIF $=1 /$ tolerance). Nilai cutoffyang umum agar mendapat hasil ada/tidak multikolinearitas dengan melihat nilai tolerance atau sama dengan nilai VIF. 
Tabel 2

Hasil Uji Multikolinearitas

\begin{tabular}{|c|c|c|c|c|}
\hline \multirow{2}{*}{ No } & \multirow{2}{*}{ Variabel Bebas } & \multicolumn{2}{|c|}{ Collinearity Statistics } & \multirow{2}{*}{ Keterangan } \\
\hline & & Tolerance & VIF & \\
\hline 1 & Harga & 0,728 & No & $\begin{array}{l}\text { Non } \\
\text { Multikolinearitas }\end{array}$ \\
\hline 2 & Inovasi Produk & 0,972 & 1,029 & $\begin{array}{l}\text { Non } \\
\text { Multikolinearitas }\end{array}$ \\
\hline 3 & Gaya Hidup & 0,711 & 1,407 & $\begin{array}{l}\text { Non } \\
\text { Multikolinearitas }\end{array}$ \\
\hline
\end{tabular}

Berdasarkan Tabel 2,kita ketahui bahwa angkatolerance melebihidari 0,1 dan nilai VIF lebih sedikit dari10. Artinya, model regresi ini tidak terdapat multikolinearitas.

Tahap ini menguji pada model regresi adakah ketidaksamaanantar variabelresidual dari 1 pengamatan ke pengamatan lain. Dikatakan model regresi yang tidak baikjika terjadi heteroskedastisitas dan baik jika homoskedastisitas (Ghozali, 2011). Melihat grafik plot dapat dijadikan cara untuk melihat apakah ada atau tidaknya heteroskedastisitas dengan ketentuan jika ada pola tertentu, contohnya titik yang penyebarannya diatasnya lalu dibawahnya angka nol pada sumbu $\mathrm{Y}$, maka dianggap tidak memiliki masalah heteroskedastisitas.

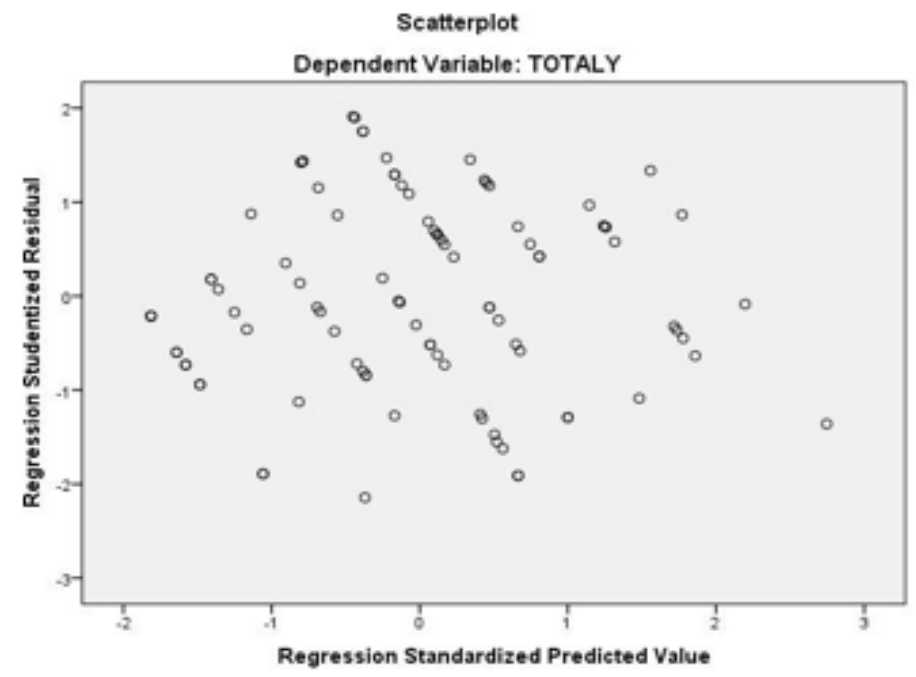

Gambar 2.

Hasil Uji Heteroskedastisitas

\section{Analisis Regresi Linier Berganda}

Analisis regresi linear berganda digunakan menggunakan alat olah data yaitu bantuan SPSS versi 20.0. Berikut merupakan ringkasan hasil output SPSS analisis regresi linear berganda nampak pada struktur hubungan kausal harga, inovasi produk dan gaya hidup terhadap pertimbangan konsumen dalam melakukan kegiatan pembelian seperti pada Gambar 3. 


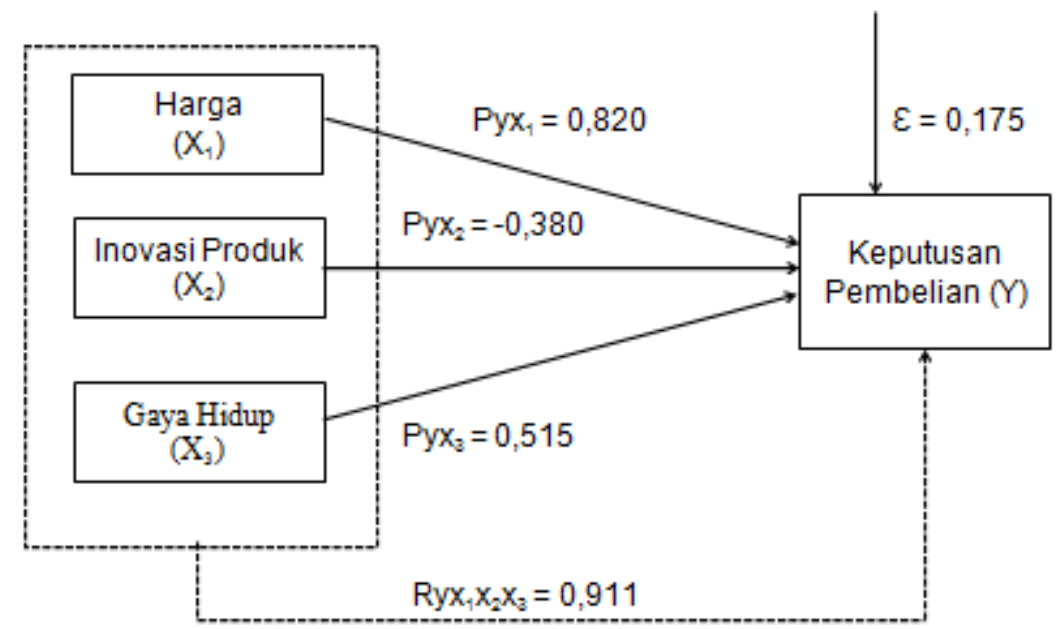

Gambar 3

Struktur Hubungan Kausal Harga, Inovasi Produk Dan Gaya Hidup Terhadap Keputusan Pembelian

Berdasarkan pada Tabel hasil pengujian hipotesis pertama, Hubungan pengaruh variabelharga $\left(\mathrm{X}_{1}\right)$,inovasiproduk $\left(\mathrm{X}_{2}\right)$ dangayahidup $\left(\mathrm{X}_{3}\right)$ terhadap keputusan pembelian $(\mathrm{Y})$ sebesar 0,911 dan sumbangan pengaruhnya sebesar $(82,5 \%)$ sedangkan sisanya dipengaruhi oleh variabel lain sebesar (17,5\%). Artinya,variabel harga, inovasi produk dan gaya hidup secara bersama-sama berperan dalam meningkatkan keputusan pembelian. Hasil penelitian ini juga didukung oleh penelitian Nurzainul dan Zulistiani (2017) yang mengemukakan bahwa variabel inovasi produk, gaya hidup dan harga berpengaruh signifikan terhadap keputusan pembelian.

Hasil uji hipotesis kedua, ada pengaruh parsial antara variabel harga terhadap keputusan pembelian. Hubungan pengaruh variabel harga terhadap keputusan pembelian sebesar 0,820 dan sumbangan pengaruh sebesar 67,2\%. Hal ini berarti harga berperan positif dalam upaya meningkatkan pertimbangan pembelian yang dilakukan konsumen. Didukung oleh Jailani (2013) yang menyatakan bahwa variabel harga berpegaruh positif dan signifikan terhadap keputusanpembelian.

Hasil pengujian hipotesis ketiga diperoleh bahwa ada pengaruh parsial antara variabel inovasi produk terhadap keputusan pembelian. Hubungan pengaruh variabel inovasi produk terhadap keputusan pembelian sebesar $-0,380$ dan sumbangan pengaruh sebesar $14,4 \%$. Hal ini berarti inovasi produk berperan negatif dalam upaya meningkatkan keputusan pembelian. Ini berarti pemasar belum mampu untuk mengembangkan inovasi terhadap kain endek sesuai dengan keinginan dan kebutuhan pasar yang ada.

Hasil pengujian hipotesis keempat diperoleh bahwa Ini berarti produsen belum cukup kemampuannya untuk melakukan inovasi terhadap kain endek sesuai dengan keinginan juga kebutuhan pasar. Didukung oleh Salim (2011) yang menemukan bahwa gaya hidup berpengaruh positif terhadap keputusanpembelian.

\section{Simpulan Dan Saran}

Berdasarkan hasil dan pembahasan yang dilakukan, penulis tarik kesimpulan: (1) keputusan pembelian kain endek di Pasar Semarapura dipengaruhi secara positif dan signifikan oleh harga, inovasi produk dan gaya hidup. Hal ini menunjukkan semakin tinggi harga, inovasi produk dan semakin meningkatnya gaya hidup orang, maka semakin meningkat juga keputusan untuk pembelian, (2) keputusan pembelian kain endek di Pasar Semarapura dipengaruhi secara positif dan signifikan oleh harga. Artinya, apabila harga tinggi, maka keputusan pembelian akan semakin meningkat, (3) keputusan pembelian kain endek di Pasar Semapura dipengaruhi secara negatif dan signifikan oleh inovasi produk. 
Artinya, jika inovasi produk tinggi, maka keputusan pembelian rendah, (4) keputusan pembelian kain endek di Pasar Semarapura dipengaruhi secara positif dan signifikan oleh gaya hidup. Artinya, jika gaya hidup konsumen tinggi, maka semakin tinggi pula melakukan

Beberapa saran yang penulis berikan : (1) Untukpenelitian yang akan dilakukan kedepannya diharapkan dapat menggunakan metode dan teknis analisis lain dalam meneliti harga, inovasi produk dan gaya hidup atau dengan menambahkan variabel $X$ lainnya yang dapat berpengaruh pada keputusan pembelian dan dapat merelasikan teori lainnya berkaitan pada variabel yang digunakan,(2) Untuk pedagang yang berjualan di Pasar Semarapura, diharapkan untuk dapat memahami apa yang menjadi keinginan konsumen seperti dari faktor harga mendapatkan potongan, ataupun inovasi-inovasi produk sesuai dengan permintaan pasar.

\section{Daftar Pustaka}

Abdillah, T.A. 2017. Pengaruh Promosi Dan Inovasi Produk Terhadap Kepuasan Konsumen Dan Dampaknya Terhadap Keputusan Pembelian Ulang Pada Online Shop Miulan Hijab. Semarang: Universitas Diponegoro

Agustina, L, Dkk. 2019. Pengaruh Gaya Hidup, Harga, Promosi,Citra Merek, Dan Viral Marketing Terhadap Keputusan Pembelian Smartphone Oppo. e - Jurnal Riset Manajemen

Cannon, P., McCarthy. 2008. Manajemen Pemasaran. Jakarta: Salemba Empat

Ghozali, I. 2011. Aplikasi Analisis Multivariate dengan Program IBM SPSS 19. Semarang: Badan Penerbit Universitas Diponegoro

Hendariningrum. R., M.E.S. 2008. Fashion Dan Gaya Hidup : Identitas Dan Komunikasi. Jurnal Ilmu Komunikasi, Vol. 6. No. 2

Jailani, A.S. 2013. Pengaruh Harga, Kualitas Produk Dan Region Of Origin Terhadap Keputusan Pembelian Kaos Cak Cuk Di Surabaya. Jurnal Bisnis dan Manajemen. Vol. 6. No. 1

Kotler, P dan K.L. Keller. 2009. Manajemen Pemasaran Jilid 1. Edisi Kedua belas. Indeks. Jakarta

Nathaniel, G.B.S. 2019. Pengaruh Gaya Hidup Dan Inovasi Produk Terhadap Keputusan Pembelian Produk (Studi Pada Perempuan Yang Membeli Brand Zara Di Grand Indonesia Jakarta). Jurnal Administrasi Bisnis Vol. 72 No. 2.

Nurzainul, E., Zulistiani. 2017. Pengaruh Inovasi Produk, Gaya Hidup, Harga, Terhadap Keputusan Pembelian Minyak Rambut Stalker Pomade (Studi Kasus Pada Pembeli Minyak Rambut Stalker Pomade Di Un Pgri Kediri). Jurnal Simki-Economic Vol. 01 No.01

Saputra, R., dkk. 2015. Pengaruh Inovasi Produk Dan Promosi Terhadap Keputusan Pembelian Pada Distro Klanrock House Concept Store Di Jember. E- Sospol Xxx Saraswati, Md L. 2014. Pengaruh Desain Produk, Kualitas Produk, dan Harga Terhadap Keputusan Pembelian Pada Kampung Batik Wiradesa, Kabupaten Pekalongan. Jurnal IImu Administrasi Bisnis

Setiadi, J.N. 2003. Perilaku Konsumen. Edisi 1. Jakarta: Prenada Media

Shaleh, R. 2017. Pengaruh Inovasi Produk, Gaya Hidup, Harga, terhadap Keputusan Pembelian Minyak Rambut Stalker Pomade (Studi Kasus pada Pembeli Minyak Rambut Stalker Pomade di UN PGRI Kediri. Jurnal Simki Economic. Vol. 1, No. 1. 
Tamamudin. 2012. Analisis Pengaruh Pengenalan Merek, Persepsi Kualitas, Harapan Konsumen Dan Inovasi Produk Terhadap Keputusan Membeli Dan Dampaknya Pada Loyalitas Konsumen (Studi Kasus: Produk Batik Sutra Halus Merek Tamina). Jurnal Penelitian, Vol 9. No. 2. 289-295

Waskiarani, L.G.I., Sulistyawati, E. 2013. Faktor-Faktor Yang Dipertimbangkan Konsumen Dalam Keputusan Pembelian Produk Endek Di Kota Denpasar. 